\title{
Ensuring LNG Liquefaction Facility's System Integrity: Pipe Pneumatic Testing as a "Build it Tight" Attribute
}

\author{
Nirmal Surendran Menon \\ Associate Member, Institution of Mechanical Engineers (IMechE), Graduate Member, Engineering New Zealand \\ Email: nirmalsurendranmenon[at]gmail.com \\ Cell: +1(337)-965-4978
}

\begin{abstract}
In reservoirs, natural gas is found in three states - i.e. - non-associated, where there is no oil contact; gas cap, where it is overlying an oil reserve; and associated gas, which is dissolved in the oil. Composition of the natural gas defines how it will be processed for transport. Whether staying in its gaseous state or being transformed into a liquid, natural gas from the well must undergo separation processes to remove water, acid gases and heavy hydrocarbons from the recovered natural gas. The next step in processing is determined by what type of transport the gas will undergo, and specifications are met according to the transportation system. One such transportation is by liquefying the natural gas, called as Liquefied Natural Gas (LNG). Natural gas is liquefied by lowering the temperature of the hydrocarbon to approximately $-260^{\circ} \mathrm{F}$. This temperature drop liquefies the natural gas, making transportation possible at atmospheric pressure in the form of LNG. The liquefaction of Natural Gas is carried out in facilities called as LNG trains which has a complex network of pipelines running between different sections inside the train. All these pipelines inside the LNG train should be leak proof to avoid any release of hydrocarbon to atmosphere during normal plan operation. Pressure testing is a method used to perform strength and leak tests of a pipeline involved in hydrocarbon transportation. This article focuses on the importance of pneumatic pressure testing of piping system transporting hydrocarbons (Natural Gas in particular) as a clean and safer method ensuring the system is built tight.
\end{abstract}

Keywords: Pneumatic Pipe Testing, System Integrity, Build-It-Tight (BIT), Pre-Commissioning, Internal Design Gauge Pressure, Piping System, Test Pressure, Repair, Field, P\&ID, Piping Isometric, Line-list

\section{Introduction}

This article covers the preparation, arrangement, procedures, and evaluation criteria for pipe pneumatic pressure testing to be performed prior to pre-commissioning and should not be confused with the tightness test performed by commissioning. For LNG facilities, it is always better to keep the pipelines dry to the maximum extent possible and carrying out pneumatic test in critical services lines which shall be stealth from water is the best option. Prior to 1955, the pressure testing, if performed, was usually performed utilizing the commodity being transported as the test fluid. To limit the loss of commodity in case of a failure, the testing pressures ranged between 5 psig to $50 \mathrm{psig}$, or 10 percent higher than the operating pressure of the pipeline. One of the first documented pressure tests using water occurred on the "Big Inch" and "Little Big Inch" product pipelines, known as "Inch Lines." The lines were acquired on May 1, 1947, and the operator began the process of rehabilitating the product pipelines to transport natural gas (The Big Inch and Little Big Inch Pipelines" Texas Eastern Transmission Corporation, May 2000). During the conversion process, the operator experienced numerous failures due to pipe manufacturing defects and pipe corrosion. In 1950, hydrostatic pressure testing of the pipelines was completed well above the MAOP, sometimes to 100 percent Specified Minimum Yield Strength (SMYS) or higher. As a result of this experience, the natural gas industry performed scientific studies between 1953 and 1968 to better understand the benefits, limitations and workings of hydrostatic pressure testing. Over time, operators began to adopt the practice of hydrostatic pressure testing with water to higher stress levels than had previously been customary and eventually went up to carrying out pneumatic testing. The principle objective of the method described herein is the detection, location, and evaluation of leaks within a pipe section containing field butt welds, flanges and other mechanical joints. This is applicable to piping and piping systems in compliance with all Design Codes, Specifications and Recommendations currently recognized by the appropriate Regulatory Authority. All pressure testing of pipe work shall, as a minimum, meet the requirements of the following Codes, Standards, and Regulations: ASME B31.3Process Piping - ASME Code for Pressure Piping B31.3 Version 2012, ASME B16.34-Valves Flanged, Threaded and Welded Ends, NFPA 11-Standard for Low- Medium and High Expansion Foam, NFPA 13-Standard for the Installation of Sprinkler Systems, NFPA 15-Standard for Water Spray Fixed Systems for Fire Protection, NFPA 20-Standard for the Installation of Stationary Pumps for Fire Protection, NFPA 24-Standard for the Installation of Private Fire Service Mains, NFPA 59A-Standard for the Production Storage and Handling of Liquefied Natural Gas (LNG), ASME PCC-2 Article 5.1 Appendix III Version 2011 along with project specific procedures such as ITP for Installation of Piping Systems, Pipe Testing Procedure, Technical Specification for General Pipe Weld Examination Requirements, Technical Specification for Field Pressure Testing of Piping, Technical Specification for Bolt Torqueing and Tensioning, Environment Management Plan.

\section{Test Planning}

\section{A. General}

The general arrangement for pneumatic pressure testing is shown in Figure A-1. Required relief valve setting pressure shall be in accordance with Figure A-1. Relief valve shall be calibrated and have current calibration certification available at all times. The set pressure shall not be higher than the test pressure plus the lesser of 50 psi or $10 \%$ of the test pressure. All PSV's are to be calibrated every 12 months as a minimum. If a PSV is found defective or not holding at 
specified pressures then the PSV is to be recalibrated or removed from service. Analogue pressure gauges shall have a starting range from zero and have the ability to read 1.5 times of the test pressure for test. Gauges are to be stored and handled in a safe manner. All Analogue (Dial indicator) Pressure gauges are to be calibrated every six months. Digital Pressure Gauges shall be factory calibrated and shall require re-calibration every 12 months and have current calibration certification available at all times. The test fluid shall be dry nitrogen or clean, dry, oil-free air. Industrial style air compressor with a dryer package shall be used. Air quality shall be checked prior to filling any system to be tested. All flanges in the system to be tested shall be securely taped and a pinhole shall be provided around the flange in the tape for leak detection (Upon successful completion and acceptance on any test all tape shall be removed and disposed of as per project environmental requirements regarding waste management). All anchors, supports, guides and hangers shall be checked for correct installation. Expansion joints with tie rods and retaining nuts shall be installed in the test position in accordance with manufacturer's recommendations. Blinds at valves and system extremities shall be checked for correct location and thickness. All in-line manual valves (except check valves) shall be clearly identified on the system test pack P\&ID. They shall be in the fully open position during the pressure test, but not back seated so as to test the valve stem packing, unless otherwise specified. Ball Valves shall be stroked during pressurization to allow pressure equalization of the body cavity, before returning to the fully open position for the duration of the pressure test. It is important that soft seated valves are not left in the $1 / 2$ open position (or similar) for a sufficient period as to cause indentations on the seat inserts. The supplier's recommendations shall be fully complied with during these activities. Check valves shall be removed for all pressure testing activities. All piping and equipment which are to be leak tested shall have formal QA/QC written clearance to confirm all requirements have been met, any punch list items cleared and system is released for leak testing. Prior to testing all piping shall be flushed to remove all internal debris, refer to Specification. Piping to be tested may be fully painted as per the piping isometric.

\section{B. Exclusion Zone Determination}

Exclusion zone distances are calculated, using the equations mentioned below:

$\mathrm{Pt}$ (test pressure to be used in psig) $=1.1 \mathrm{xP}$

$\mathrm{V}$ (total volume under pressure in cubic feet

$\mathrm{E}=360 \mathrm{xPatxV}\left[1-(\mathrm{Pa} / \mathrm{Pat})^{\wedge} 0.286\right]$

$\mathrm{E}=$ stored energy $(\mathrm{ft}-\mathrm{lb})$

$\mathrm{Pa}=$ absolute atmospheric pressure (14.7psia)

$\mathrm{Pat}=\mathrm{absolute}$ test pressure $=\mathrm{Pt}+\mathrm{Pa}$

TNT $=\mathrm{E} / 1488617$

$\mathrm{R}=$ Minimum Safe Distance for the exclusion zone

$\mathrm{R}=100 \mathrm{ft}$ for $\mathrm{E}<100,000,000 \mathrm{ft}-\mathrm{lb}$

$\mathrm{R}=200 \mathrm{ft}$ for $100,000,000 \mathrm{ft}-\mathrm{lb}<\mathrm{E}<200,000,000 \mathrm{ft}-\mathrm{lb}$

$\mathrm{R}=\operatorname{Rscaled}(\mathrm{TNT})^{\wedge} 1 / 3(\mathrm{PCC}-2-2011$ Article $5.1 \mathrm{App} . \mathrm{III})$

$\mathrm{R}=\operatorname{Rscaled}(2 \mathrm{TNT})^{\wedge} 1 / 3(\mathrm{PCC}-2-2015$ Article 5.1 App. III)

Calculations based on ASME PCC-2, Article 5.1/ 2011 and 2015 Version, where

$\mathrm{R}=$ actual distance from equipment and piping

Rscaled $=50 \mathrm{ft} / \mathrm{lb}^{\wedge} 1 / 3$

Exclusion Zone Calculations were based on the references and equations quoted in "Explosion Hazards and Evaluation"
Elesevier Scientific Publishing Company, Amsterdam, 1983, pp 463-474 (Baker W E et al. 1983). The following assumptions are made: (a) The largest dead-ended branch connections in a piping system will generally be an instrument, vent or drain connection with a maximum diameter of 2 inches. Furthermore for nozzle necks exceeding 12 inches long the distance travelled by the projectile will not increase significantly. Therefore, the credible projectile is 2 inches; 12 inches long, (b) The initial velocity at detachment depends on the stored energy of the compressed gas inside the system, (c)No energy is transferred to the nozzle from the compressed gas in the main pipe run or equipment item, (d)All the energy from the compressed gas in the branch connection is adiabatically converted into kinetic energy when the nozzle becomes detached, (e)The energy required to break the branch weld, overcome friction losses as the gas escapes and to cause the tumbling nozzle to rotate is ignored, (f)The drag area of the nozzle as it tumbles is the average of its face areas, (g)The only resistance to the flight of the nozzle is the still air. Above assumptions (d), (e) and (f) are conservative whereas assumptions (a), (b), (c), and (g) are not. On balance, it is considered that the deviations cancel out and that the rounded up calculated distances travelled by the projectile tabulated in Figure A-2 are realistic. Plans for access to the test area shall be based on the calculated stored energy and the requirements of Figure A-2. It must be strongly emphasized that the consequences of pneumatic test failure such as projectile discharge, discharge jet of high pressure gas, and potential violent dislodgement of fabricated piping are all life threatening events and hence exclusion zones shall be rigidly enforced. The access to the system to be pneumatically tested is determined by calculating the distance travelled by a projectile, which is considered to be the most likely type of failure. The distance travelled by such a projectile is a function of mass, initial velocity after detachment and its aerodynamic profile. For piping systems the possible types of failure are:(a)Brittle fracture of a pipe creating small shrapnel projectiles with small aerodynamic profile, (b)Butt weld failure of pipes up to 6 inches causing them to whip or "snake". However, the remainder of the pipe still attached restricts this effect and therefore the exclusion distance does not have to be large, (c) Although it would be catastrophic, butt weld failure of pressure vessels, exchangers or equipment within a piping system is not considered to be a credible event during a pneumatic test, since all this equipment will have been shop hydro tested, (d) Sudden detachment of a branch welded nozzle connection or other pipe attachment. This would result in a tumbling projectile, which could travel a large distance and could cause significant injury or loss of life. It is not practicable or possible to $100 \%$ radiograph branch welds due to their geometry. Therefore, a failure here is considered to be far more likely that butt welds which have been $100 \%$ radio graphed. Exclusion distances have therefore been calculated for the "guillotine failure" and detachment of a small nozzle connection welded to a larger pipe or to an item of equipment.

\section{Required Non-destructive Examinations (for piping systems to be pneumatically tested)}

When individual pipe spools have been hydrostatically tested to the requirements of ASME B31.3 in a fabrication shop or in a field lay-down area, the following Non-destructive Examinations are required for field-welded seams prior to pneumatic testing: (a) All field butt welded seams: 100\% 
radiography using the acceptance criteria for "Normal Fluid Service" of Table 341.3.2A of ASME B31.3. (b) All field non-butt pressure boundary welds: $100 \%$ magnetic particle (for ferrite material) or liquid penetrant (for non-ferrite material) of root and final passes. (c) The limited access area applies only to those field welds not previously pressure tested. If the piping spools have not been hydrostatically tested to the ASME B31.3 required leak test pressure, the following Non-destructive Examinations are required prior to the pneumatic test: (a) All butt welds: 100\% radiography, using the acceptance criteria for "Normal Fluid Service" of Table 341.3.2A of ASME B31.3. (b) All non-butt pressure boundary welds: $100 \%$ magnetic particle (for ferrite material) or liquid penetrant (for non-ferrite material) of root (if possible) and final passes. (c) The limited access area applies to all components of the pressurized system. For pipe that is equal to or smaller than 24 inches, a field pneumatic test may be conducted without imposing any additional Nondestructive Examinations beyond those listed by the material and piping specifications if the following criteria are satisfied:(a) The pneumatic test pressure is equal to or less than $100 \mathrm{psi}(\mathrm{g})$, and (b) The total stored energy in the system being tested is less than $100000000 \mathrm{ft}-\mathrm{lb}$. For welded pipe that did not receive a mill or shop hydrostatic test, the total stored energy is limited to $25000000 \mathrm{ft}-\mathrm{lb}$. Stored Energy $\mathrm{E}=$ stored energy (ft-lb) is calculated as below:

$\mathrm{E}=360 x \mathrm{Pat} x \mathrm{~V}\left[1-(\mathrm{Pa} / \mathrm{Pat})^{\wedge} 0.286\right]$

$\mathrm{Pa}=$ absolute atmospheric pressure (14.7psia)

$\mathrm{Pat}=$ absolute test pressure $=\mathrm{Pt}+\mathrm{Pa}$.

\section{Minimum Metal Temperature}

The minimum metal temperature during the field pneumatic test must not be less than the warmer of the following: (a) The coldest specified temperature in Table B-1 for the most restrictive category of pressure retaining material. This shall be defined by the responsible Engineer, (b)The warmest Minimum Design Metal Temperature (MDMT) of ASME Section VIII, Division 1 or Division 2 vessels included in the test, if such vessels have been previously pressure tested per the Code, (c)For other equipment constructed of impact tested materials, and having been previously pressure tested per their construction codes, the minimum metal temperature for the leak test may be lowered to $63^{\circ} \mathrm{F}$ warmer than the warmest temperature at which the materials were impact tested. For piping systems that contain equipment that has been in service, the equipment manufacturer shall specify the minimum metal temperature for pneumatic testing. Pressurizing shall not commence until the metal temperature has reached the required value or warmer. Consideration shall be given to heat loss during the test to assure that the minimum metal temperature is retained while the piping or piping system is pressurized. Take temperature readings of metal at various locations to assure that it is warmer than the coldest temperature allowed. Temperatures may not fall below the coldest allowed with the system test in progress. If it is speculated that the minimum temperature allowed will be exceeded during the test duration the test shall not commence.

\section{Testing Procedures and Durations}

Prior to commencement of Pneumatic test, a preliminary pressure test of the injection hoses (hose injecting air to the system to be tested) shall be conducted at test pressure to ensure there are no leaking hose connections. No exclusion zone is required for the hose check as the hoses are pre-tested and certified by the supplier. Ensure hose restraints are fitted at every hose connection. Confirm all personnel are outside the exclusion zone. Gradually raise the pressure of the system until the pressure is the lesser of $25 \mathrm{psi}$ or $25 \%$ of the test pressure. Pressure should be held and maintained for 10 minutes to allow the system to equalize. Prior to snooping, the entire line being tested shall be "walked" to determine if there is any audible evidence of leakage. Snoop test joints using chloride-free leak detection fluid (ordinary soaps or detergents are not allowed). After initial snoop test has taken place and it has been agreed that no leaks have been detected, all personnel involved with this activity must sign out of the exclusion zone via one single point. When all personnel have been accounted for, the pressurization can continue to the greater of either 50 psi or $35 \%$ of the test pressure. Pressure shall be held and maintained for 10 minutes to allow the system to equalize. The pressure shall be gradually increased to the test pressure in steps. At each of the holding steps; pressure should be held and maintained for 5 minutes to allow the system to equalize. If pressure loss is observed, the system pressure should be reduced to $25 \%$ of the test pressure and check for leaks. Once the full test pressure is reached ( $110 \%$ of design), pressure should be held and maintained for 10 minutes to allow the system to equalize If no pressure loss is observed, reduce the pressure to $100 \%$ of the Design pressure and hold to 10 minutes to allow the system to equalize. If no pressure loss is observed, walk the entire line being tested for evidence of leakage. If no evidence is observed, then snoop test joints. After second snoop test has taken place and it has been agreed that no leaks have been detected, all personnel involved with this activity must sign out of the exclusion zone via one single point. After successful completion of the test, the system shall be depressurized at no greater than $25 \mathrm{psi}$ per minute. Once Snoop test is successfully conducted, the exclusion zone can be reduced to a minimum distance of $50 \mathrm{ft}$. After successful completion of test, the system shall be depressurized at no greater than 25 psi per minute. The blow-down valve shall be opened gradually during depressurization. During depressurization metal temperature shall be monitored local to the vent location(s) for stored energy greater than 200 million $\mathrm{ft}-\mathrm{lb}$ to ensure metal temperature doesn't fall below $32^{\circ} \mathrm{F}$. The ramp up chart for pneumatic testing is shown in Figure A-3.

The pneumatic test duration for various conditions is as shown in the Table B-2

\section{Tools and equipment required for carrying out air-blowing}

The running time calculation for compressor that is used to feed the piping system to be tested is shown in Appendix VI. Based on the test pressure, the load on the compressor can be determined and the test duration can be computed based on which the ramp up chart can be plotted.

\section{Testing Pressures}

The pneumatic test pressures (except as noted in ASME B31.3 Section 345.4.3) shall be $\mathrm{Pt}=1.10 \mathrm{P}$, where $\mathrm{Pt}$ is the test pressure and $\mathrm{P}$ is the design pressure as shown in the line 
list. Firewater test pressure shall be per NFPA 11, NFPA 13, NFPA 15, NFPA 20 AND NFPA 24, as applicable.

\section{Test Acceptance Criteria}

A Pneumatic test on a piping system is accepted provided the following conditions are met; the test pressure is maintained for a minimum of ten (10) minutes and no leaks detected in a welded joint or in a parent pipe during the test, no Leaks are observed in any permanent Flange Joints / Assemblies. Flange joints at which a blank or blind is used to isolate equipment or other piping during a test, need not be leak tested in accordance with the para 345.1 of ASME B31.3. Minor leak will not constitute a rejection if the test medium is continuously added to compensate for known leaks so that test pressure is maintained. (Reference ASME B 31.3 Para 345.2.3 and Interpretation: 22-14 of ASME B31.3). Any deformation or leakage of parts or a component of the piping system, exclusive of possible localized instances at pump or valve packing, constitutes a failure. Any bubbles observed because of seepage shall be cause for rejection. Seepage at blind points or temporary components is not a cause for rejection as long as source of problem is recognized and isolated, the full extent of the system has been otherwise accepted per the test procedure, and the integrity of the permanent plant system under inspection is not in question.

\section{Leak Correction}

For Pneumatic Test, in the event that any flange or mechanical joint leaks, the leak is to be marked and the pipe system depressurized to 25 psi or below for tightening. If a flange or mechanical joint requires to be disassembled, then the joint is to be marked and the pipe system depressurized to 0 psi. If leaking occurs at a weld, the weld shall be marked and the pipe system depressurized to 0 psi and repair shall be carried out.

\section{Repairs}

Acceptability of repaired areas shall be determined by a retest.

\section{Retest Criteria}

Failures shall be investigated, defective material or workmanship shall be repaired or replaced and the system shall be retested. Any modification to the pressure-containing boundary shall also call for a retest. In case, a flange requires machining and it is in the code tolerance than it does not call for a retest.

\section{Test Records}

Records shall be kept of testing operations and a complete report, including a copy of the records, charts, etc., shall be maintained after the operations are completed. The records shall include the following:(a) Date of test, (b)Clean and concise marked up P\&ID showing the test system and test limits, (c)Location/Unit,(d)Test medium,(e)Test pressure,
(f)Test duration, (g)Metal temperature,(h)Certification by tester, (i)Calibration certification for all testing equipment, (j) Approval by Owner's Inspector with sign off, (k)List of all piping isometric and P\&ID's included in the test, (l)Punch list of all outstanding work. All relevant calibration and certification documents relating to all test equipment including relief valves and gauges should be included in the package.

\section{Conclusion}

Pneumatic pressure testing of pipeline system is an excellent alternative compared to carrying out hydrostatic testing if all the pre-test preparations are carried out in a step by step manner and all the pre-test safety conditions are fulfilled as pneumatic testing is precise and is able to detect even a pinhole leak even in welded joints which might go undetected during a hydrostatic test ensuring the facility system has been "BUILT TIGHT".

Reference to this paper should be made as follows: Surendran Menon, N., (2019) 'Ensuring LNG Liquefaction Facility's 'System Integrity': Pipe Pneumatic Testing as a "Build it Tight" Attribute",.

\section{References}

[1] ASME B31.3 Process Piping - ASME Code for Pressure Piping B31.3. Version 2012

[2] ASME B16.34 Valves Flanged, Threaded and Welded Ends

[3] NFPA 11 Standard for Low- Medium and High Expansion Foam

[4] NFPA 13 Standard for the Installation of Sprinkler Systems

[5] NFPA 15 Standard for Water Spray Fixed Systems for Fire Protection

[6] NFPA 20 Standard for the Installation of Stationary Pumps for Fire Protection

[7] NFPA 24 Standard for the Installation of Private Fire Service Mains

[8] NFPA 59A Standard for the Production Storage and Handling of Liquefied Natural Gas (LNG).

[9] Explosion Hazards and Evaluation" Elsevier Scientific Publishing Company, Amsterdam, 1983, pp 463-474

[10] The Big Inch and Little Big Inch Pipelines" Texas Eastern Transmission Corporation, May 2000

\section{Author Profile}

Nirmal Surendran Menon received his Bachelor of Engineering in Mechanical from Anna University, Tamil Nadu, India in 2005 and Master of Science in Project Management from National University of Singapore in 2010. He has more than 12 years of experience in EPC projects in the Oil/Gas/Petrochemical sector. He is currently working as Field Engineer in an LNG Liquefaction Project in South West Louisiana, US. His interests include pipeline system integrity, pipeline system cleanliness, Loss Prevention in LNG liquefaction facilities as part of project execution. 
Figure A-1

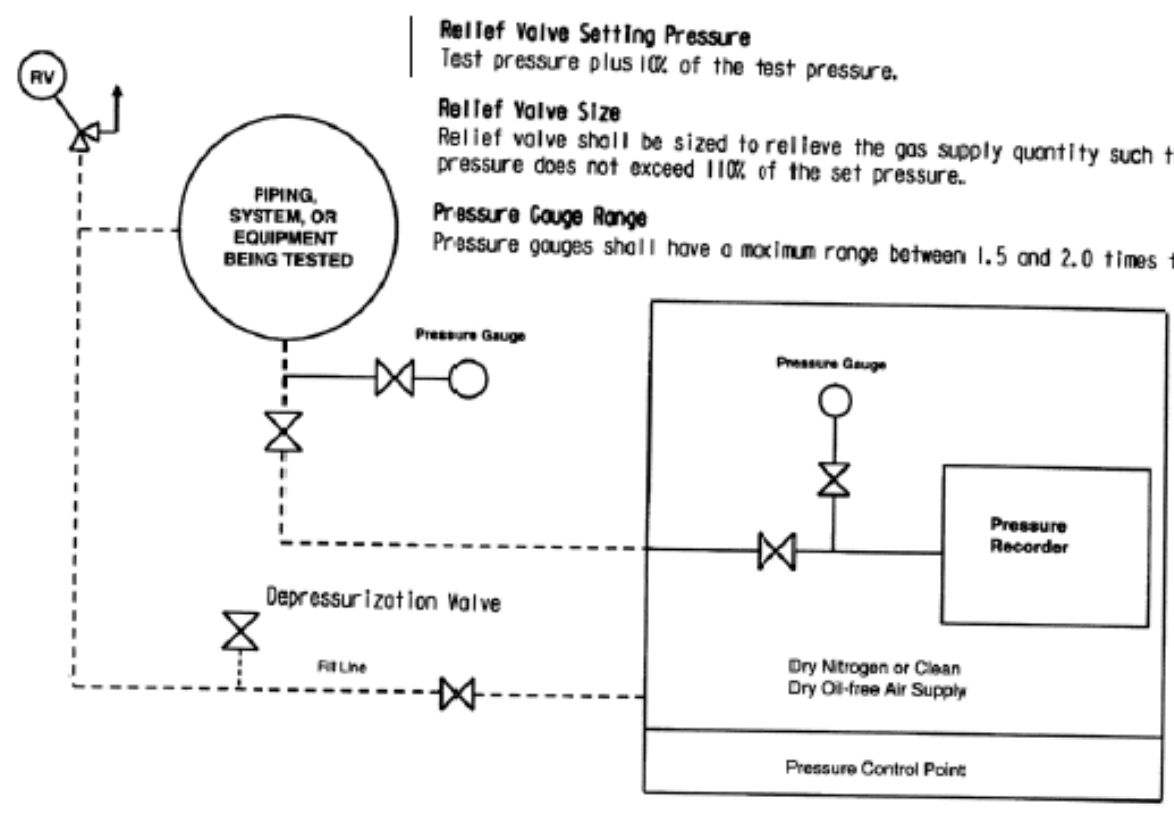

Figure A-2

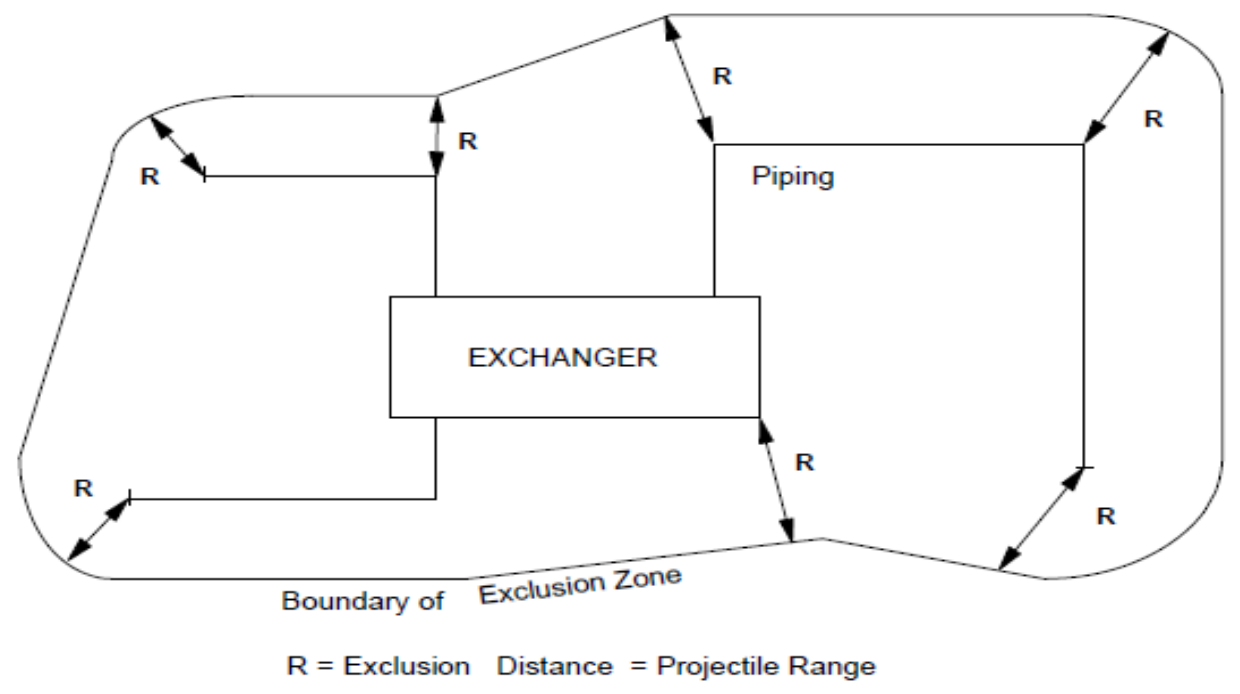

Figure A-3

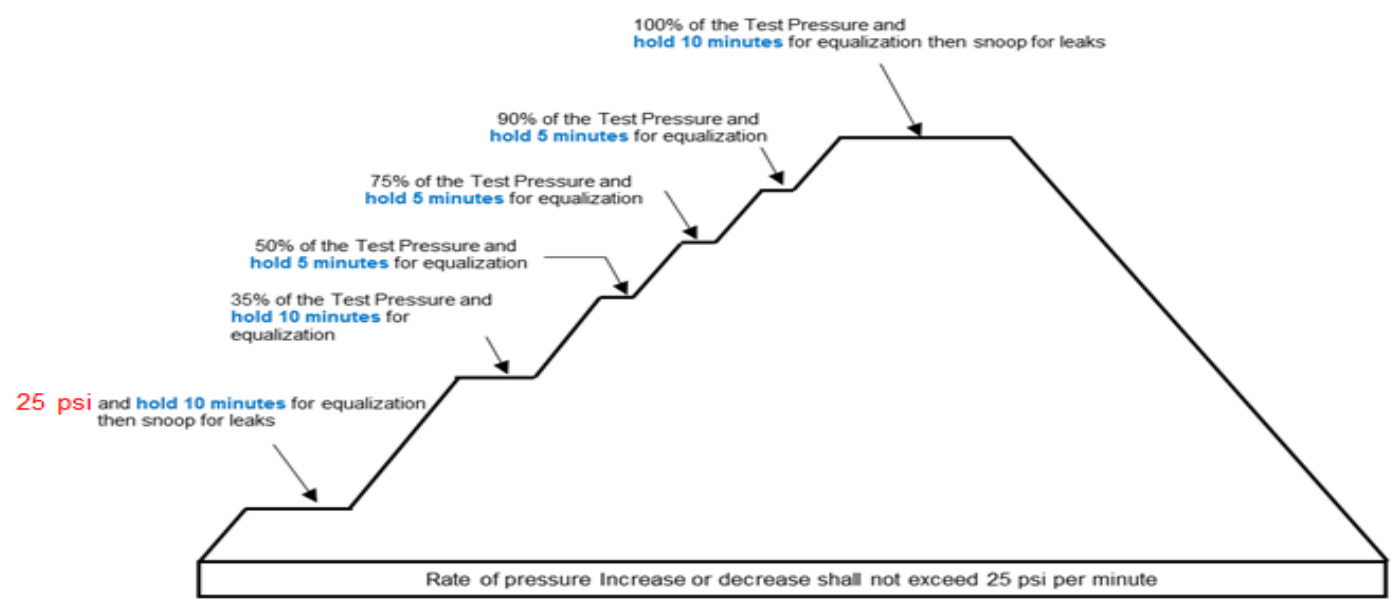

Volume 8 Issue 1, January 2019 www.ijsr.net

Licensed Under Creative Commons Attribution CC BY 
International Journal of Science and Research (IJSR)

ISSN: 2319-7064

Index Copernicus Value (2016): 79.57 | Impact Factor (2018): 7.426

Table B-1

MINIMUM METAL TEMPERATURE AT TIME OF TESTING (Note 1)

\begin{tabular}{|c|c|c|c|c|}
\hline \multirow[t]{2}{*}{ Category } & \multirow{2}{*}{$\begin{array}{l}\text { Materials and Basis Description } \\
\text { (Notes } 1 \text { and 2) }\end{array}$} & \multirow{2}{*}{\begin{tabular}{|c|} 
Nominal \\
Wall \\
Thickness \\
mm \\
(Note 5) \\
\end{tabular}} & \multirow{2}{*}{$\begin{array}{c}\text { PWHT } \\
\text { (Note 6) }\end{array}$} & $\begin{array}{l}\text { Coldest } \\
\text { Metal } \\
\text { Temp } \\
\end{array}$ \\
\hline & & & & ${ }^{\circ} \mathrm{C}$ \\
\hline $\begin{array}{c}\text { A } \\
\text { (Note 3) } \\
\text { (Note 6) }\end{array}$ & $\begin{array}{l}\mathrm{P} 1 \mathrm{or} \mathrm{P} 3 \text { carbon or low alloy classified in Table A-1 (Note 6) } \\
\text { as }-28.8^{\circ} \mathrm{C} \text { or Curve B, } \mathrm{C} \text {, or D in Figure } 323.2 .2 \text {. Coldest } \\
\text { temperature from Curve B at } 19 \mathrm{~mm}+17^{\circ} \mathrm{C}\end{array}$ & $\leq 19$ & No & 7.2 \\
\hline $\begin{array}{c}\text { B } \\
\text { (Note 6) }\end{array}$ & $\begin{array}{l}\text { Category A welded spools that have been PWHT because } \\
\text { one or more of the Nominal wall thicknesses at the weld is } \\
>19 \mathrm{~mm} \text {. Coldest temperature from Curve B Fig. } 323.2 .2 \\
\text { using maximum nominal thickness. }\end{array}$ & $>19$ & Yes & $\begin{array}{l}\text { Per Fig. } \\
\text { 323.2.2A, } \\
\text { Curve B }\end{array}$ \\
\hline $\begin{array}{c}\mathrm{C} \\
\text { (Note 6) }\end{array}$ & $\begin{array}{l}\text { P1 or P3 carbon or low alloy classified in Table A-1 (Note 6) } \\
\text { as Curve A, also including valve body castings per Note } 4\end{array}$ & $\leq 19$ & No & 28 \\
\hline D & $\begin{array}{l}\text { Category C spools that are PWHT, maximum nominal } \\
\text { thickness at weld }\end{array}$ & $\begin{array}{c}\text { Max. } \\
\text { nominal } \\
\text { Thickness }\end{array}$ & Yes & \begin{tabular}{|} 
Per Fig. \\
$323.2 .2 \mathrm{~A}$, \\
Curve A
\end{tabular} \\
\hline $\mathrm{E}$ & $\begin{array}{l}\text { Combination of Category A, B, C, or D. The warmest } \\
\text { temperature controls. }\end{array}$ & - & - & - \\
\hline $\begin{array}{c}\mathrm{F} \\
\text { (Note 6) }\end{array}$ & $\begin{array}{l}\text { P3, P4 or P5 alloy steels classified in Table A-1 with a } \\
\text { minimum temperature of }-28.8^{\circ} \mathrm{C} \text { that are not required to be } \\
\text { PWHT } t \leq 13 \mathrm{~mm}\end{array}$ & $\leq 13$ & No & $\begin{array}{c}\text { Same as } \\
\text { Category } \\
\text { A }\end{array}$ \\
\hline G & $\begin{array}{l}\text { Category F spools for which the entire welded assembly is } \\
\text { required to be PWHT }\end{array}$ & $\begin{array}{l}\text { may be } \\
>13\end{array}$ & Yes & \begin{tabular}{|c|} 
Same as \\
Category \\
B
\end{tabular} \\
\hline H & Fully austenitic welded piping assemblies & No Limit & No & 0 \\
\hline
\end{tabular}

Notes to Table B-1

1. Materials in welded piping assemblies (spools) or systems consisting of pipe, forgings, fittings, valves and supports. Applies to flanges, fittings, and valves conforming to ASME or MSS standards only.

2. ASTM materials unless otherwise noted. ASME materials have the same designation as the ASTM materials, but prefixed by an "S" (e.g., SA-516). ASME materials shall be in accordance with ASME Section II-Part A.

3. Welded piping assemblies (spools) or systems containing cast steel valve bodies in ASTM A216 WCB or WCC shall be tested as per Category $\mathrm{C}$

4. Includes cast steel valve body materials that are A-216 Grades WCB and WCC if not made to fine grain practice and water quenched and tempered, and A-217 Grade WC6 normalized and tempered or water-quenched and tempered

5. The thicknesses indicated for flanges, fittings, forgings, and castings are at the ends at which butt welds are made

6. All table and figure references are to ASME B31.3. For PWHT definitions and requirements, as per Table 331.1.1

Volume 8 Issue 1, January 2019 www.ijsr.net

Licensed Under Creative Commons Attribution CC BY 
International Journal of Science and Research (IJSR)

ISSN: 2319-7064

Index Copernicus Value (2016): 79.57 | Impact Factor (2018): 7.426

Table B-2

\begin{tabular}{|c|c|c|c|c|}
\hline Test Type & Condition & Test Pressure Stages/Duration & Test Duration & Reference Code \\
\hline Pneumatic & $\begin{array}{l}\text { Test Pressure <100psi } \\
\text { Other than Polypropylene }\end{array}$ & $\begin{array}{l}\text { 1) Lesser of } 50 \% \text { of test pressure or } 25 \text { psi HOLD @ } 10 \text { mins [Snoop] } \\
\text { 2) } 60 \% \text { of test pressure HOLD for } 10 \text { mins } \\
\text { 3) } 90 \% \text { of test pressure HOLD for } 5 \text { mins } \\
\text { 4) } 100 \% \text { of test pressure HOLD for } 10 \mathrm{mins} \text { (min) } \\
\text { 5) Reduce to design pressure HOLD for } 10 \mathrm{mins} \text { (min) [Snoop] } \\
\text { 6) Depressurize to "0" (max } 25 \text { psi per minute) }\end{array}$ & $10 \mathrm{mins}(\min )$ & $\begin{array}{l}\text { ASME B31.3 para } 345.5 .5 \\
\text { ASME B31.3 para 345.2.2(a) }\end{array}$ \\
\hline Pneumatic & \begin{tabular}{|l} 
100psi $\leq$ Test Pressure $<300 p s i$ \\
Other than Polypropylene
\end{tabular} & 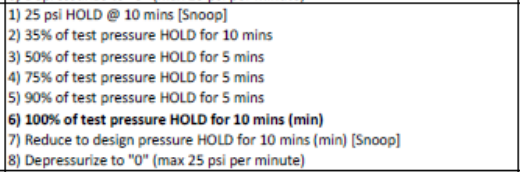 & $10 \mathrm{mins}(\mathrm{min})$ & ASME B31.3 para 345.5.5 \\
\hline Pneumatic & $\begin{array}{l}\text { Test Pressure } 2300 \text { si } \\
\text { Other than Polypropylene }\end{array}$ & $\begin{array}{l}\text { 1) } 25 \text { psi HOLD @ } 10 \text { mins [Snoop] } \\
\text { 2) } 35 \% \text { of test pressure HOLD for } 10 \text { mins } \\
\text { 3) } 50 \% \text { of test pressure HOLD for } 5 \text { mins } \\
\text { 4) } 60 \% \text { of test pressure HOLD for } 5 \text { mins } \\
\text { 5) } 70 \% \text { of test pressure HOLD for } 5 \text { mins } \\
\text { 6) 80\% of test pressure HOLD for } 5 \text { mins } \\
\text { 7) } 90 \% \text { of test pressure HOLD for } 5 \text { mins } \\
\text { 8) } 100 \% \text { of test pressure HOD for } 10 \text { mins (min) } \\
\text { 9) Reduce to design pressure HOL for } 10 \text { mins (min) [Snoop] } \\
\text { 10) Depressurize to "0" (max } 25 \text { psi per minute) }\end{array}$ & $10 \mathrm{mins}(\min )$ & ASME B31.3 para 345.5.5 \\
\hline $\begin{array}{ll}\text { Pneumatic } \\
\end{array}$ & NIRON Polypropylene & 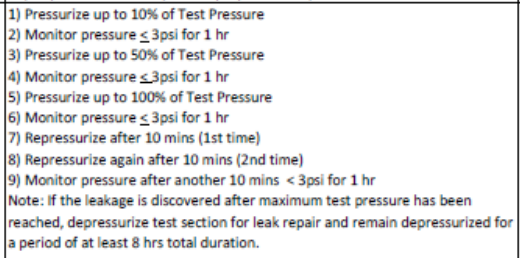 & $2.5 \mathrm{hrs}$ (min) & \\
\hline
\end{tabular}

Table B-3

\section{Running time calculation sheet for Pnuematic test}

A) INPUT INFORMATION

\begin{tabular}{|c|c|c|}
\hline Design Pressure & $\mathrm{Pd}$ & psi \\
\hline Test Pressure & $\mathrm{Pt}$ & psi \\
\hline Test Volume & $\mathrm{vt}$ & $\mathrm{A3}$ \\
\hline Exclusion zone & $R$ & $\mathrm{ft}$ \\
\hline Total Output from compressor & $\circ$ & $\mathrm{f} 3 \mathrm{~m} / \mathrm{min}$ \\
\hline Output compressor-1 & 01 & $\mathrm{f} 33 / \mathrm{min}$ \\
\hline Output compressor-2 & 02 & $\mathrm{f} 33 / \mathrm{min}$ \\
\hline Output compressor-3 & 03 & $\mathrm{f} 33 / \mathrm{min}$ \\
\hline \begin{tabular}{|l|} 
Max filling rate limitation \\
\end{tabular} & $\mathrm{Rm}$ & psi/min \\
\hline Pressure at 1 ATM & $\mathrm{Pa}$ & psi \\
\hline
\end{tabular}

B) CALCULATION

\begin{tabular}{|c|c|c|c|c|c|c|}
\hline Function & System P. & Unit & Formula-1 & Time [min] & Formula-2 & Actual Time [min] \\
\hline Step-1: Increse Pressure from 0 to "P1" (25 psi) & $P 1=25$ & psi & $\Delta P 1$ & & & \\
\hline \begin{tabular}{|l|} 
Volume for compressor \\
\end{tabular} & & $\mathrm{ft} 3$ & $(\triangle P 1 \times V t) / P a$ & & $((\Delta \mathrm{P} 1 \times \mathrm{V} \mathrm{V}) / \mathrm{Pa}) / 0$ & \\
\hline \begin{tabular}{|l|} 
Holding time for equalization \\
\end{tabular} & & $\min$ & & & & \\
\hline Snoop time & & $\min$ & & & & \\
\hline Step-2 : Increse Pressure from "P1" to "P2" (35\% Pt) & $\mathrm{P} 2=35 \% \mathrm{Pt}$ & psi & $\triangle P 2$ & & & \\
\hline Volume for compressor & & $\mathrm{Al} 3$ & $(\triangle \mathrm{P} 2 \times \mathrm{Vt}) / \mathrm{Pa}$ & & $((\Delta \mathrm{P} 2 \times \mathrm{V} t) / \mathrm{Pa}) / 0$ & \\
\hline \begin{tabular}{|l|} 
Holding time for equalization \\
\end{tabular} & & $\min$ & & & & \\
\hline Step-3 : Increse Pressure from "P2" to "P3" (50\% Pt) & $\mathrm{P} 3=50 \% \mathrm{Pt}$ & psi & $\triangle P 3$ & & & \\
\hline \begin{tabular}{|l|} 
Volume for compressor \\
\end{tabular} & & $\mathrm{A} 33$ & $(\triangle P 3 \times V t) / P a$ & & $((\Delta \mathrm{P} 3 \times \mathrm{V} t) / \mathrm{Pa}) / 0$ & \\
\hline \begin{tabular}{|l|} 
Holding time for equalization \\
\end{tabular} & & $\min$ & & & & \\
\hline Step-4 : Increse Pressure from "P3" to "P4" (75\% Pt) & $\mathrm{P} 4=75 \% \mathrm{Pt}$ & psi & $\Delta P 4$ & & & \\
\hline Volume for compressor & & $\mathrm{A} 3$ & $(\triangle \mathrm{P} 4 \times \mathrm{Vt}) / \mathrm{Pa}$ & & $((\Delta \mathrm{P} 4 \times \mathrm{VV}) / \mathrm{Pa}) / 0$ & \\
\hline \begin{tabular}{|l|} 
Holding time for equalization \\
\end{tabular} & & $\min$ & & & & \\
\hline Step-5 : Increse Pressure from "P4" to "P5" (90\% Pt) & $\mathrm{P} 5=90 \% \mathrm{Pt}$ & psi & $\triangle P 5$ & & & \\
\hline Volume for compressor & & $\mathrm{AB} 3$ & $(\triangle P F \times V t) / P a$ & & $((\Delta \mathrm{P} 5 \times \mathrm{V} \mathrm{V}) / \mathrm{Pa}) / 0$ & \\
\hline \begin{tabular}{|l|} 
Holding time for equalization \\
\end{tabular} & & $\min$ & & & & \\
\hline Step-6: Increse Pressure from "P5" to "P6" (100\% Pt) & $P 6=100 \% \mathrm{Pt}$ & psi & $\triangle P B$ & & & \\
\hline Volume for compressor & & $\mathrm{A} 33$ & $(\triangle \mathrm{PB} \times \mathrm{Vt}) / \mathrm{Pa}$ & & $((\Delta \mathrm{PB} \times \mathrm{V} \mathrm{t}) / \mathrm{Pa}) / \mathrm{O}$ & \\
\hline \begin{tabular}{|l|} 
Holding time for equalization \\
\end{tabular} & & $\min$ & & & & \\
\hline Step-7: Reduce Pressure from "P6" to "P7" (Pd) & P7 $=$ Pd & psi & $\triangle P 7$ & & $(\Delta P 7 / R m) \times 2$ & \\
\hline \multirow[t]{2}{*}{\begin{tabular}{|l|} 
Holding time for equalization \\
\end{tabular}} & & $\min$ & & & & \\
\hline & & & Sub-total time & & & \\
\hline \multirow[t]{2}{*}{ Snoop time for leak } & & $\min$ & & & & \\
\hline & & & Sub-total time & & & \\
\hline \multirow[t]{2}{*}{ Step-8 : Reduce Pressure from "P7" to "P8" (0 psi) } & $P 8=0$ & psi & $\triangle P 8$ & & $(\triangle P 8 / R m) \times 3$ & \\
\hline & & & Total time & & & \\
\hline
\end{tabular}

Volume 8 Issue 1, January 2019

www.ijsr.net

Licensed Under Creative Commons Attribution CC BY 